\title{
特集 脑神経外科手術と高次脳機能
}

\section{頭部外傷と高次脳機能障害}

\author{
大 東 祥 孝
}

\section{Traumatic Brain Injury and Higher Brain Dysfunction}

by

Yoshitaka Ohigashi, M.D.

from

Graduate School of Human and Environmental Studies, Kyoto University

Higher Brain Dysfunctions following Traumatic Brain Injury and possible treatment approaches to these dysfunctions are described. We often observe pathological symptoms related to frontal and temporal lesions rather than "aphasia, apraxia, agnosia" in the narrow sense, after TBI. Clinical pictures that frequently appeared are as follows: (1) apathy or aspontaneity, (2) disinhibition, (3) executive dysfunction, (4) memory deficit, (5) attention deficit, (6) repetitive stereotypy, (7) stimulus bound behavior, (8) semantic memory deficit, (9) social interaction deficit or delusion and (10) loss of awareness.

(Received November 10, 2008 ; accepted December 2, 2008)

Key words : traumatic brain injury, cognitive dysfunction

$$
\text { Jpn J Neurosurg（Tokyo） } 18: \text { 271-276, } 2009
$$

\section{はじめに}

まず，重篤な頭部外傷の 1 例を提示し，さまざまな問 題点を具体的に示す.

\section{【症例 F】}

\section{患 者: 23 歳, 男性. 右利き}

19 歳の時, ヘルメットなしでバイク運転中に交通事故 に遭い, 脳挫傷, 両側硬膜外血腫をきたし, 減圧術（両 側頭蓋骨除去）が施行された。四肢の運動麻痺などの重 大な神経症状をほとんど残さずに，事故後約 1 年して自 宅に戻ったが，意欲の低下（アパシー）とともに，衝動 性, 易怒性, 強迫性, 常同的行動が顥在化し, 介護に難 渋し, 数力月前から精神科に入院し, 薬物療法, 行動観 察を行いながら，今後の治療方針，介護方針，家庭復州
の可能性を模索中である.

表情に乏しく，無関心で，自発的に自分から何かをす るということはほとんどないが，少しでも注意されたり すると異様なほどに怒りをあらわにする，拳を握りしめ て，相手に殴りかからんばかりの攻撃性をみせる，毎日 することといえば，常同的反復的にスーパーへ行ってお 菓子を買うことと, 神社へ行って一周して特に何もする ことなく䚻ってくるということの繰り返しで，1 人で外 出すると他人とさまざまなトラブルを起こしたりするた めに，常に誰かが付いていなければならず，ついに家人 の負担は限度を超光, 精神科病院へのしばらくの入院を 余儀なくされた。

CTではFig. 1 のように, 両側性の前頭葉・側頭葉前方 部のきわめて広汎な脳挫傷を認め, SPECT でも同様の部 位に広汎な血流低下を認めた。一般に頭部外傷の際は, 


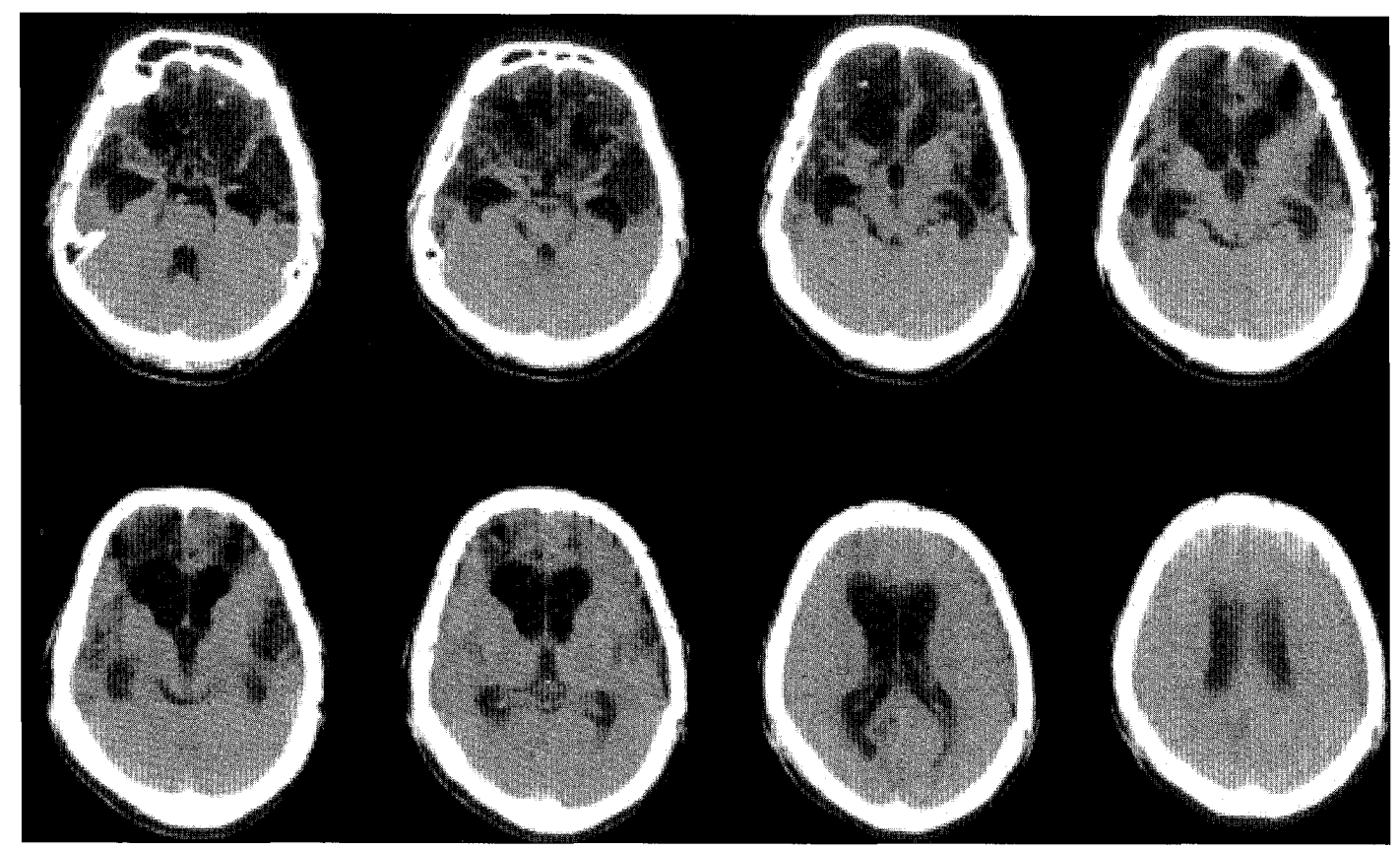

Fig. 1 CT finding of Case F

直接的な損傷部位のいかんにかかわらず，前頭葉～側頭 葉前方部に損傷を被ることが多い2)が，この症例はその 典型例であるといってょい．頭部外傷後遺症としての高 次脑機能障害で頻度の高い症状の多くは, 前頭葉ないし 側頭葉前方部の機能障害と関連を有している。そうした 場合，核心にあったはずの，その人の「人格」がすっか り変化してしまい，「もはや以前の彼/彼女ではない」と いう印象を与えることがしばしばある1)。何が変化した かというと, アパシー, 無関心, 脱扣制, 易怒性, 自己 意識の稀薄さなどに由来すると思われる「対人相互性, 社会性の欠如」である。

記憶障害が目立つ場合もまれではない。この症例の場 合には, 狭い意味の時間的, 場所的見当識は比較的保た れていたが, 自己の置かれた状況に対する無関心と相 まって，なぜこうして今，自分はこのような状沉にある のか, という本来の意味での「見当識」がほとんどなく, 日々の体験に対する想起も,きわめて不良であった。い てみれば, 蓄積された自身の過去を想起することをせず, その場その場の現在を生きている，という印象がきわめ て強い病態を示していた。

言葉は，ほぼ事故前と同様にしゃべるだけの潜在的能 力はあるようだが, 自らしやべろうとしないし, 話しか けてもごく短い言葉で,「知らん」,「わからん」というの みなので, とりつくしまがない。言葉も行動も，きわめ て「社会性」に乏しいのである.

しかしながら,ゆっくりと時間をかけて調べてみると， 例えば MMSE (mini-mental state examination) では 24/
30 と, 想像以上に高い得点を示し, 一定の認知機能が残 存していることが明らかになった。脳の後方領域は，そ れ自体としてはかなりのレベルで働いているのである が，それが実際の社会生活に反映されることがないので ある。しかし，そうした残存する認知機能をうまく使え るように周囲が工夫していけば，たと六重篤な障害が あっても，ある程度「人間的な生活」を取り戻すことが 不可能ではない場合もある。本例も, 薬物療法と認知社 会行動療法とを併用して関与するうちに，数力月後には 比較的穏やかになって, 多少とも対人関係における変化 がみとめられはじめ, 家庭復帰を期待できる程度にまで 「社会性」が回復してきている。むろん，まだまだアパシー などの症状は強く残存しているが，時には笑顔もみられ るようになり，「人間的な生活」への回復に向けたかすか な希望がみえはじめている，といった状況である。

この症例に象徵される事態が, 頭部外傷例ではよく認 められる.以下に, 生じやすい症状について具体的に概 説しこうした症例に対する「対応のありかた」につい ても可能な範囲で触れておきたいと思う。

\section{脳挫傷とび漫性軸索損傷}

脳挫傷は, 直接に外傷を受けた部位やその反対部位の 損傷 (contre-coup) とともに, 頭蓋構造と脳の位置関係 のゆえに, どこに直接的損傷を被っても, 前頭葉下内側 面, 側頭葉前方部下面に損傷が生じやすいことはよく知 られている(Fig. 2)。そのことと関連して, 脸外傷では, 

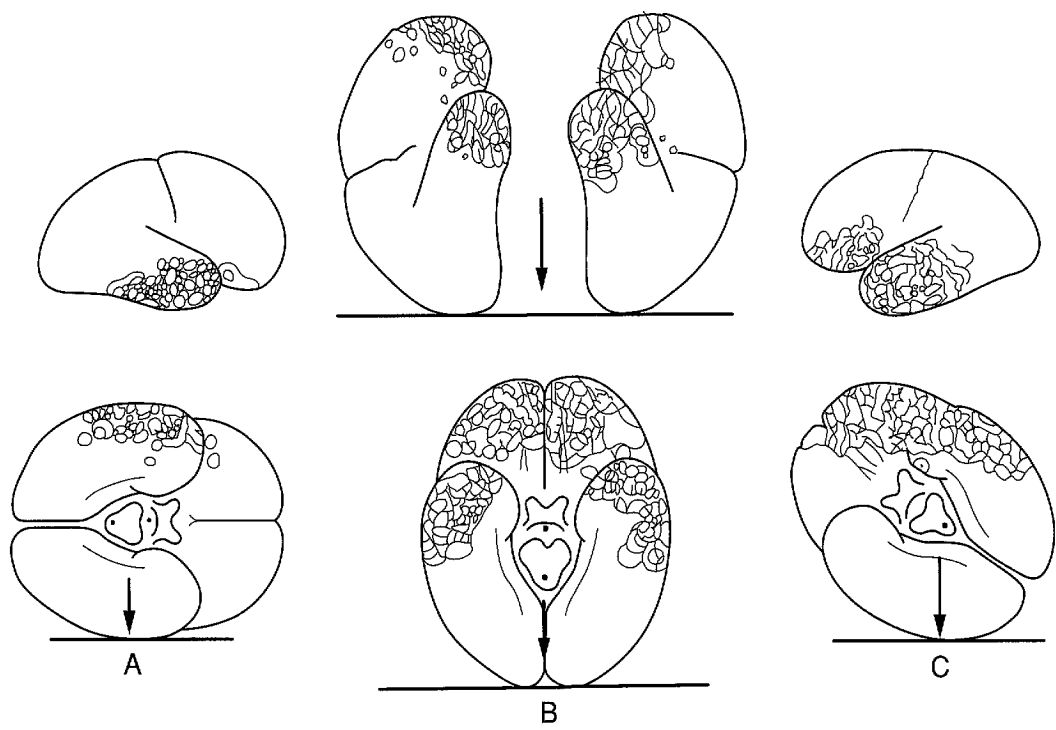

Fig. 2 Vulnerable regions for traumatic brain injury

後方病変によって比較的生じやすい,いわゆる「失語・失 行・失認」症状については, 比較的少ないか, あっても 程度が軽く, 目立つのはやはり前頭葉・側頭葉前方部病 変による高次䋞機能障害であるといってよい778).

一方, び漫性軸索損傷（DAI； diffuse axonal injury）の 影響が最近, 注目を集めている。DAI の生じやすい場所 としては, 脳梁, 深部白質領域, 脳幹部などが知られて きているが，その画像による検出は必ずしも容易ではな く, 発症早期の CT 画像や MRI (T2 強調画像), 3T-MRI, さらにはDTI (diffuse tesor imaging) などによって, 微 少出血 (micribleeding) の確認をする方法が行われてい る。 DAI は, 必ずしも頭部外傷の重症度に比例せず，白 質, 脳梁などに認められる場合がまれではなく, 注意機 能, 遂行機能, 記憶機能などに影響を及ぼし, 精神運動 性緩除（bradyphrenia）を惹起する可能性が指摘されてい る. 判断の難しい点はあるが, 頭部外傷後の高次脳機能 障害に対しては, 少なくとも脳挫傷とともに DAI の影響 を常に考慮しておく必要があると考光られる。

\section{比較的多い高次脳機能障害}

脳挫傷が前頭葉と側頭葉前部に生じやすいために，比 較的出現頻度の高い症状としては, 次のようなものが挙 げられる5゙。

1) apathy（自発性低下，アパシー)

2 ) disinhibition（脱抑制，社会行動障害）

3) executive dysfunction（遂行機能障害）

4 ) memory deficit (記憶障害)

5 ) attention deficit (注意機能障害)
6 ) repetitive stereotypy（反復・滞続・常同症）

7) stimulus bound behavior（被影響性症状）

8 ) semantic memory deficit（意味記憶障害）

9 ) social interaction deficit, delusion(対人相互性障害, 妄想性障害)

10） loss of awareness（気づきの欠如）

すでに述べたように，狭義の「失語・失行・失認」症 状は，比較的少なく，あってもあまり重度とはい光ない ことも少なくない. したがって, 以下に, 上述の症状に ついての概説を行うことにする.

\section{1 自発性低下, アパシー (apathy)}

自分からはほとんど何もしなくなるが，外から刺激が 与えられると, 一定の反応を示す傾向がみられる。外界 で生じている出来事に「無関心」になっているが，うつ (depression) とは異なり, 悲哀感を示すことはほとんど ない. 時に「強迫症状」や「常同行動」を伴う。前頭葉 内側面-基底核-視床回路との関連が指摘されているが, 前頭葉背外側面, 前頭葉内側底面でも若干ニュアンスを 異にしてアパシーがみられることもある(10).

\section{2 眖抑制 (disinhibition)}

社会的な許容の範囲を超えた逸脱行動がみられる，表 現型としては, 易怒性, 性的脱抑制, 䇗盗, ギャンブル などがある，そうした行動について，本人は「してはい けないこと」と自ら述べながらも，これを抑制すること ができない，してしまった後で，「もう，絶対にしない」 と謝りはするが，深刻味に欠け，現実吟味に乏しく，同 じことを繰り返す．前頭葉眼窩面（内側底面）の損傷で 


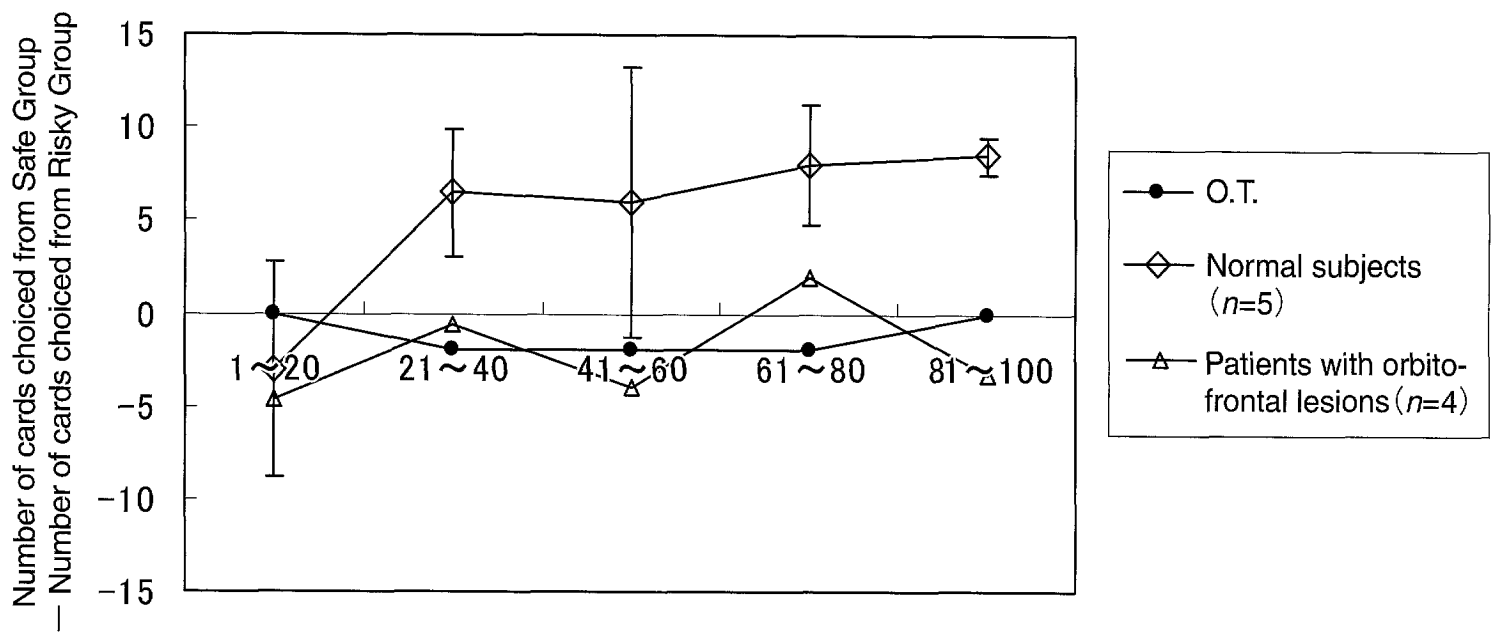

Fig. 3 Results of a gambling task. While normal subjects gradually avoid risky choices, patients with orbitofrontal lesions continue to choose risky items.

みられることが多い. ギャンブリング課題を行うと，八 イリスクの山を引き続けるので, ある程度, 検査でチェッ クできる（Fig. 3）

\section{3 遂行機能障害 (executive dysfunction)}

ルーチン化した手法では解決できない課題に出会った 時や，同時に複数の課題をこなさねばならない時に，当 惑し，強い困難を覚える．WCST (Wisconsin card sorting test）や TMT (trail making test) などで成績が低下する. 前頭葉背外側部-基底核-視床回路, あるいはび漫性軸索 損傷などで，しばしば認められる。

\section{4 健忘症状 (amnesia)}

前脳基底部 (basal forebrain), 側頭葉内側面（海馬近 傍）の損傷で, 体験記憶（エピソード記憶）の障害が出 現しうる。したこと，話したこと，頼まれたこと，置い た場所など, 自身の過去の体験が想起できない症状，有 関係, 無関係対語記憶課題, 再認課題や Rey の複雑図形 の遲延再生などで検査する。

\section{5 注意障害 (attention deficit)}

うっかりミスが目立つ，集中ができないといった症状 として認められる.PASAT (paced auditory attention test： 1 秒おき, 2 秒抢きに数字を聞かせ, 直前の数字と聞い たばかりの数字の和を答えていく検査）や，ランダムな 系列文字を抹消していく視覚検出末梢検査などで判定す る.

\section{6 反復・滞続・常同症 (repetitive stereotypy)} 同じことを何度も繰り返し行い, 語る。パターン化し た行動を示すことも多い. 決まった場所を同じルートで 歩きまわることもよくみられる，同時に，強迫的，常同 的に, 長時間にわたって手を洗ったり, 歯を磨いたり, 風吕に出入りしたり, シャワーを浴び続けたりする。両 側側頭葉損傷, 前頭葉皮質下損傷との関連が想定されて いる.

\section{7 被影響性症状（stimulus bound behavior）}

個体の自律的意思が希薄になり，外界の刺激に容易に 誘発されて, 行動が惹起される状態. 使用行動(utilization behavior)，模倣行動（imitation behavior）などがある. 前者では, 使う必要がないのに, 視界にもの（例えば櫛 やコップ）が入ると, 対象に引きずられたように, 櫛で 髪をとき,コップの水を飲んだりする，後者では, 検者 の仕草を, 必要がないといわれても, 模倣してしまうよ うな行動として認められる。前頭葉内側面損傷との関連 が想定されている。

\section{8 意味記憶障害 (semantic memory deficit)}

一見，対象の名前がいえない（語健忘）ようにみえる が，その語の意味が不全化もしくは艇失していることが 病態の本質である。語を聞いても対象を指示できなかっ たり，理解できなかったりする，言葉だけではなく，モ ノ自体やヒトにまで及ぶ意味記憶の障害がみられること もある，両側側頭葉（側頭極）から中側頭回を中心とす る病変によって生じる可能性が高い。言葉の意味記憶障 害の場合は, 左側頭葉優位の病変であることが一般的で 
ある。

\section{9 対人相互性・妄想性障害 (social interaction deficit, delusion)}

頭部外傷後，数パーセントの症例において，外傷から 平均 4〜 5 年後に, 被害的幻覚妄想状態の生じうること が知られている ${ }^{11)}$ (外傷後精神病性障害：PDFTBI；psychotic disorder following traumatic brain injury). 側頭極は 扁桃体や前頭葉眼窩面と強い結合があり，その損傷に よって，相貌情動の認知や対人的な情動認知に負のバイ アスがかかり，時に被害妄想的となる可能性が指摘され ている.

\section{0 気づきの欠如（loss of awareness）}

頭部外傷後，多くの症例で，以上に述べたようなさま ざまな症状に自ら気づくことがそしいという傾向がみら れる，たとえ言語的に「わかっている」と述べても，例 えば，脱抑制的行動を自ら制止できないこと自体に気づ かない，前頭葉内側面，前部带状回などの病変や，DAI などの関与が想定されるが，確実なことはまだわかって いない ${ }^{9)}$.

\section{外傷後高次脳機能障害への対応}

脳神経外科医は，主として外傷後の急性期ないし亜急 性期に外科的な関与を求められることが一般的であり， 慢性期に入って後遺症状が前景に出るころになると, 症 状に応じて，リハビリテーション関連診療科や精神神経 科での対応が必要となってくる6)。この時期になお脳神 経外科医が関与する場合もあるが，後遺症としての認知 機能障害やさまざまな精神症状への対処は，特定の診療 科のみではなかなか解決が困難な場合も少なくなく，実 際には，脳神経外科医，リハビリテーション医，精神科 医，PT，ST な゙コ・メディカルスタッフを含む連携的 関与が求められることになる。しかし一般的にいうと， 例えば精神科医は，頭部外傷後遺症の症例を直接に診る 機会は必ずしも多くはないといった事情があるため，最 近では「高次脳機能障害」を主として専門とする精神科 医や脳神経外科医を中心に，新たな「高次脳機能障害」 外来も，徐々に開設されつつある，比較的若年者を含む 頭部外傷後遺症例が多くなってきていることに鑑みれ ば，診療科横断的・連携的な「高次脳機能障害」科の設 置が現在, 大きな社会的課題となりつつあると思われる.

ともあれ，実際の臨床場面では，さまざまな症状に応 じて以下のような対応が行われている。
脱抑制的行動，易怒性などの社会行動障害が前景に出 る場合には，介護する家族など近親者は，対応に難淽す ることが多い，とりわけ，症状に対する「気づきの欠如」， 「記憶障害」「注意障害」などが目立つことが多いため, 対 応はいっそう困難となる。アパシーや妄想性障害なども， 対応を難しくさせる要因となる。

脱抑制的行動，易怒性，妄想性障害，強迫的行動など の社会行動障害に対しては，一定の薬物療法の効果がみ られる場合もあるが，必ずしも過大な期待はできない.

使用されることの多い薬物としては,カルバマゼピン， バルプロ酸ナトリウム，オランザピン，リスペリドン， クロチアゼパム, SSRI などが, 症状に応じて比較的少量, 試みられる゙1.

記憶障害，注意障害，遂行機能障害などに対しては， 認知リハビリテーションも積極的に試みられるように なってきている。しかし，アパシーや病態に対する気づ きの欠如などは，高次脳機能障害のリハビリテーション にとって大きな障壁となる場合も少なくない.

アパシーが最も中心的な後遺症状と考元られる場合, 彼/彼女のアパシーは，その性質上，自らは何もしないが， 外からの刺激には思いの外，反応を示すこともまれでは ない，根気よく，対応を続けることによって，社会行動 面で，相応の「人間らしさ」を回復していく場合もある. 楽物療法と認知行動療法とを併用することによって，ど のあたりまでの回復が期待できるか（家庭内生活，社会 適応，職業的生活）を，みきわめることが求めら扎る。

\section{おわりに}

現実には，いろいろな治療的接近を試みると同時に， 彼/彼女らの有する障害が多少とも回復不可能な部分を 有しうることを直視し，その部分に関しては，ためらわ ずに障害をサポートする社会システムの活用に訴える心゙ きであるし，そうした障害をサポートするシステムや体 制を適切に充実させ，積極的に推進していくことが期待 されていることを,認識して扔く必要があると思われる。

\section{文 献}

1）大東祥孝：前頭葉関連症状群一認知機能と情意機能一 板倉 徹, 前田敏博編: 神経科学の基礎と臨床・前頭葉. 東京，ブレーン出版，1996，pp.93-118.

2）大東祥孝：頭部外傷. 松下正明編：臨床精神医学講座 10：(器質 - 症状性精神障害。東京，中山書店，1997, pp.385-406.

3) 大東祥孝：器質性精神障害 (Organic Mental Disorders). 多賀須幸男，尾形悦郎，石井清一編：今日の治療指針一 私はこう治療している (2000)。東京，医学書院，2000， 
pp. $289-290$.

4）大東祥孝: 発動性障害の病理を探る。高次脳機能研究 24: 184-190, 2004

5）大東祥孝：高次脳機能障害者の精神症状・行動障害とそ の対応，精神認知と OT 2:205-210，2005.

6) 大東祥孝: 神経心理学の新たな展開一精神医学の「脱構 築」にむけて一。精神経誌 108：1009-1028，2006.

7）大東祥孝：認知機能の基礎（1）. 脳外速報 18:76-81, 2008.

8）大東祥孝：認知機能の基礎 (2). 脳外速報 18:210-217, 2008 .
9）大東祥孝：病態失認。鹿島啨雄, 大東祥孝, 種村 純編： よくわかる失語症セラピーと認知リハビリテーション。 東京, 永井書店, 2008, pp.431-436.

10）大東祥孝：意欲, 発動性の障害. 鹿島晴雄, 大東祥孝, 種村 純編：よくわかる失語症セラピーと認知リハビリ テーション。東京, 永井書店, 2008, pp.537-543.

11）大東祥孝: 教育講演: 頭部外傷後精神病性障害 (PDFTBI) と側頭極損傷一妄想知覚の発現機序仮説にむ けて一. 精神経誌 111:2009 (in press).

\section{要}

旨

\section{頭部外傷と高次脳機能障害}

大東 祥孝

頭部外傷によって生じやすい高次脳機能障害について概説し，その対応について述べた，比較的出 現頻度の高いのは，狭義の「失語·失行 ·失認」よりも，前頭葉・側頭葉損傷に関連した以下のよう な症状であることを指摘し，その臨床像について述べた。(1)apathy（自発性低下，アパシー), (2)disinhibition (脱抑制, 社会行動障害), (3)executive dysfunction (遂行機能障害), (4)memory deficit (記 憶障害), (5)attention deficit (注意機能障害), (6repetitive stereotypy (反復・滞続・常同症), (7)stimulus bound behavior (被影響性症状)，(8)semantic memory deficit (意味記憶障害), (9)social interaction deficit, delusion（対人相互性障害, 妄想性障害), (10loss of awareness（気づきの欠如）. 